\title{
GACETA ILUSTRADA Y LA ACTUALIDAD ESPAÑOLA: ¿DOS ESTILOS DE VIDA?
}

\author{
GACETA ILUSTRADA AND LA ACTUALIDAD ESPAÑOLA: \\ TWO LIFESTYLES?
}

\author{
Ainara MIGUEL SÁEZ DE URABAIN \\ Universidad del País Vasco UPV/EHU \\ ainara.miguel@ehu.eus
}

\begin{abstract}
Resumen: Este trabajo se centra en el análisis de dos números de dos de las más célebres revistas ilustradas publicadas en España desde 1950 hasta 1980: La Actualidad Española y Gaceta Ilustrada. Más concretamente, se analizan las portadas, los índices, los reportajes periodísticos y los anuncios publicitarios. Los números de las revistas no se han escogido al azar. Se trata de los números del 13 y el 15 de julio de 1961, una fecha en la que ambas publicaciones celebraban (celebraban, sí) el 25 aniversario del estallido de la Guerra Civil española.
\end{abstract}

Palabras clave: Gaceta Ilustrada. La Actualidad Española.

Abstract: This work focuses on the analysis of two numbers of two of the most famous illustrated magazines published in Spain from 1950 to 1980: La Actualidad Española and Gaceta Ilustrada. More specifically, it analyzes covers, indexes, newspaper reports and advertisements. The issues of the journals have not been chosen at random. These are the numbers of July 13 and 15, 1961, a date on which both publications celebrated (celebrated, yes) the $25^{\text {th }}$ anniversary of the outbreak of the Spanish Civil War.

Key Words: Gaceta Ilustrada. La Actualidad Española. 


\section{INTRODUCCIÓN}

El objetivo de esta propuesta es, sobre todo, saber qué podía decirse de los modos, modas y maneras de la España de los 60 analizando dos revistas de la época. El tema es, ya de entrada, demodé. De hecho, es doblemente demodé, porque se trata, además, de dos revistas ilustradas que conmemoran, cada una a su manera, el 25 aniversario de la Guerra Civil española: dos viejas revistas con más de 50 años dedicadas, retrospectivamente, a la guerra del 36 . No obstante, si lo traigo aquí es esperando que cause el efecto de "reembrague" mencionado por Landowski (2007: 137), a saber, que haga recordar su propio pasado, revivir sus propias vivencias para, al volver después al aquí-ahora, estimular su adhesión al presente.

El artículo se centra, como se ha dicho, en el análisis de dos números de dos de las más célebres revistas ilustradas publicadas en España desde los años cincuenta hasta los ochenta: Gaceta Ilustrada (1956-1984) y La Actualidad Española (1952-1979). Más concretamente, se analizan portadas, índices, reportajes y anuncios publicitarios con el propósito de conocer las dos versiones diferentes de los mismos hechos que salieron a la luz al mismo tiempo, describirlas, y comprobar cómo los diferentes modos de tratar un mismo hecho noticiable construyen diferentes realidades que responden a un modo particular de ver el mundo: la ideología del medio y también, implícitas, la del grupo editor, el gobierno, los anunciantes, etc. Se trata de un estudio sincrónico; las dos Españas.

Se estudian el fondo y la forma. La configuración visual de la página es importante, porque sugiere la jerarquía (a través del peso visual) y el impacto (a través de su estética) de la noticia; refleja su relevancia. Sin embargo, aunque el diseño jerarquice, no significa nada más allá del contexto concreto (Eco, 1995: 55). Por eso, un análisis de contenido resulta indispensable. Habrá que preguntarse, entonces, qué dice cada semanario sobre la actualidad social del país, qué no dice y, evidentemente, cómo dice lo que dice.

Se analizan íntegramente dos números de las dos revistas ilustradas estudiadas: el número 497 de La Actualidad Española (publicado el 13 de julio de 1961, a seis pesetas) y el número 249 de Gaceta Ilustrada (publicado el 15 de julio de 1961, a ocho pesetas). Las fechas no se han 
escogido al azar. Lo primero que se tuvo en cuenta era que las dos revistas estuvieran en funcionamiento, lo que acotaba los años entre 1956 (año en que empieza a publicarse Gaceta Ilustrada) y 1979 (año en que termina de publicarse La Actualidad Española). Lo segundo, que las fechas fueran significativas. Así, se escogió la tercera semana de julio de 1961, fecha en que ambas publicaciones celebraban (celebraban, sí) el 25 aniversario del estallido de la Guerra Civil.

Cada uno de los números tiene unas 70 páginas, por lo que, en total, son unas 140 páginas que analizar. Tras un primer análisis de contenido cuantitativo, se utilizará la semiótica para tratar de entender qué y cómo consiguen comunicar algunos de los textos más significativos.

\subsection{Las revistas}

La Actualidad Española y Gaceta Ilustrada fueron dos revistas ilustradas de información general que publicaron, sobre todo, crónicas de la actualidad política y cultural tanto nacional como internacional. Las dos aparecieron durante la segunda década de posguerra y fueron de las primeras publicaciones españolas en utilizar el huecograbado de color. Sus historias son paralelas.

El primer número de La Actualidad Española salió el 12 de enero de 1952, a cinco pesetas. La fundaron el periodista Jesús María Zuloaga, el político y director general de información Florentino Pérez Embid, y el catedrático Antonio Fontán. Pero la revista vivió su mejor etapa entre 1960 y 1975, durante la dirección de José Luís Cebrián Boné, cuando alcanzó uno de los primeros puestos entre las publicaciones de información general de la época (200.000 ejemplares). A partir de 1975, los lectores empezaron a fallar. Como ya veían "la actualidad" por televisión, preferían comprar revistas del corazón o de moda y belleza; La Actualidad Española cerró el 7 de enero de 1979, sin despedirse de ellos.

La Actualidad Española fue una revista visiblemente conservadora $\mathrm{y}$, aunque a partir de mediados de los sesenta trató de moderarse y adaptarse a los nuevos tiempos, estuvo hasta su penúltimo año regida por miembros del Opus Dei.

El primer número de Gaceta Ilustrada apareció cuatro años después, el 13 de octubre de 1956, estrechamente vinculado al catolicismo y editado por el Grupo Godó. El primer director de la revista fue Manuel Jiménez 
Quílez, conocido como "el periodista católico", pero fue la dirección de Manuel Suárez Caso, otro periodista católico, la que la condujo al éxito, entre 1958 y 1976 (100.000 ejemplares). A partir de entonces, empezó el declive de la revista hasta que dejó de publicarse el 16 de febrero de 1984.

Gaceta Ilustrada fue una revista católica, pero bastante moderada y liberal teniendo en cuenta el país y el régimen en que se publicaba. Tenía vocación de magacín. Fue, en palabras de los periodistas Ignacio Fontes y Manuel Ángel Menéndez (2004: 441), “el primer magacín español de información general que importó técnicas anglosajonas, incluidas las técnicas de distanciamiento"; porque Gaceta Ilustrada no quería ser falangista ni gubernamental, ni tampoco popular, y se inspiraba en el espíritu de modernidad de la francesa Paris Match y la americana Life, aunque no dispusiera ni de su libertad ni de sus medios. Sí tenía, sin embargo, un buen equipo profesional y una nómina de colaboradores eminentes. Destacan las críticas de Pedro Laín Entralgo (teatral), Julián Marías (cinematográfica) y Antonio Tovar (literaria); los reportajes y entrevistas de Oriana Fallaci y Raymond Cartier; y las fotografías de los admirables Oriol Maspons, Francesc Català-Roca, Xavier Miserachs, Ramón Masats, Julio Ubiña y Colita.

A la hora de interpretar estas páginas, tendremos que tener en cuenta tanto el trasfondo cultural y lingüístico del que habla Eco (1997: 82) como la revista en la que aparecen. Es decir, no podemos olvidar que cada una de las páginas analizadas está situada en una revista distinta, bajo un membrete que la enmarca tanto literal como metafóricamente; "El medio es el mensaje", dijo MacLuhan. De ahí la necesidad de recopilar una serie de datos generales de identificación de ambas revistas ilustradas, lo que Kayser (1966) denominó su personalidad.

\begin{tabular}{|l|l|l|}
\cline { 2 - 3 } \multicolumn{1}{c|}{} & \multicolumn{1}{c|}{ La Actualidad Española } & \multicolumn{1}{c|}{ Gaceta Ilustrada } \\
\hline $\begin{array}{l}\text { Sede de la } \\
\text { administración y de la } \\
\text { redacción }\end{array}$ & Madrid & $\begin{array}{l}\text { Madrid y talleres en } \\
\text { Barcelona }\end{array}$ \\
\hline Fecha de su fundación & $1952-1979$ & $1956-1984$ \\
\hline $\begin{array}{l}\text { Zona principal de } \\
\text { difusión }\end{array}$ & $\begin{array}{l}\text { Nacional, revista de } \\
\text { información general escrita en } \\
\text { español }\end{array}$ & $\begin{array}{l}\text { Nacional, revista de } \\
\text { información general } \\
\text { escrita en español }\end{array}$ \\
\hline
\end{tabular}




\begin{tabular}{|l|l|l|}
\hline Tirada & $\begin{array}{l}\text { Unos 200.000 ejemplares en } \\
\text { su mejor época (1960-1975); } \\
\text { datos sin confirmar. }\end{array}$ & $\begin{array}{l}\text { Entre 150.000 y 100.000 } \\
\text { ejemplares vendidos de } \\
\text { media entre 1963 y 1976, } \\
\text { según datos de OJD. }\end{array}$ \\
\hline Precio & 6 pesetas en 1961. & 8 pesetas en 1961. \\
\hline Formato & 27 x 34cm en 1961. & 28,3 x 36,8cm en 1961. \\
\hline Número de ediciones & $\begin{array}{l}\text { Semanario, 27 años, 1.350 } \\
\text { revistas. }\end{array}$ & $\begin{array}{l}\text { Semanario, 28 años, 1.400 } \\
\text { revistas. }\end{array}$ \\
\hline Grupo editor & $\begin{array}{l}\text { SARPE (Sociedad Anónima } \\
\text { de Revistas, Periódicos y } \\
\text { Ediciones) }\end{array}$ & $\begin{array}{l}\text { La familia del conde de } \\
\text { Godó, propietaria del } \\
\text { diario La Vanguardia. }\end{array}$ \\
\hline Director & $\begin{array}{l}\text { José Luís Cebrián Boné en } \\
1961 .\end{array}$ & $\begin{array}{l}\text { Manuel Suárez-Caso en } \\
1961 .\end{array}$ \\
\hline
\end{tabular}

\section{ANÁLISIS}

\subsection{Los tipos de texto}

Para identificar los tipos de texto que analizaremos, se utiliza una breve ficha, adaptada a partir del método hemerográfico propuesto por Amparo Moreno Sardà (1998: 167-188) para el análisis de contenido cuantitativo. Nos interesan:

1. El número de identificación del texto.

2. El tipo de texto (unidad comunicativa): administrativo, publicitario o redaccional ${ }^{1}$ ).

3. El número de página donde se ubica.

4. El titular: se transcribe textualmente.

5. La autoría: quién elabora el reportaje (redactor o colaborador, agencia, redacción, corresponsal).

${ }^{1}$ Como explica Josep María Casasús (1985: 79), la "superficie redaccional es aquella que la Redacción está encargada de cubrir con su trabajo. Se trata de toda la superficie cubierta con trabajos periodísticos de cualquier género. Por otra parte, la superficie administrativa es aquella que ha sido cubierta por elementos de la empresa editora aparentemente ajenos a la tarea periodística. En la superficie administrativa entran la cabecera del diario, los precios de venta y de suscripción". No creemos que las superficies o unidades publicitarias necesiten explicación. 
Las 68 páginas de La Actualidad Española se dividen entre:

$\square$ Portada

Tipo de texto redaccional: 39 páginas y media (6 reportajes)

Tipo de texto publicitario: 25 páginas (39 anuncios)

$\square$ El resto, 2 páginas y media, son pasatiempos (media página), humor (página y media) y un trabajo de costura (media página)

Las 72 páginas de Gaceta Ilustrada se distribuyen entre:

$\square$ Portada

$0 \quad$ Tipo de texto redaccional: 36 páginas y media (17 reportajes)

0 Tipo de texto publicitario: 32 páginas (50 anuncios)

El resto, 2 páginas y media, son pasatiempos (2 medias páginas) y humor (3 medias páginas)

Estos primeros datos ya nos ofrecen tres pistas. La primera, que las revistas ilustradas de los 60 eran, como las revistas de moda y belleza de hoy, vehículos publicitarios, pues el $37 \%$ de las páginas de La Actualidad Española y el $44 \%$ de las de Gaceta Ilustrada están dedicadas a la publicidad. La segunda, que la cartera publicitaria de Gaceta Ilustrada era mayor que la de La Actualidad Española. La tercera, que su temática era mucho más variada. ¿Sería por eso por lo que atraía a más anunciantes? No tenía más lectores y por eso, quizá, la compra de espacio fuera más barata. Pero aún es pronto para sacar conclusiones.

\subsection{Las portadas}

La representatividad y la importancia mediática de las portadas es indudable. Y estas dos son muy diferentes. 


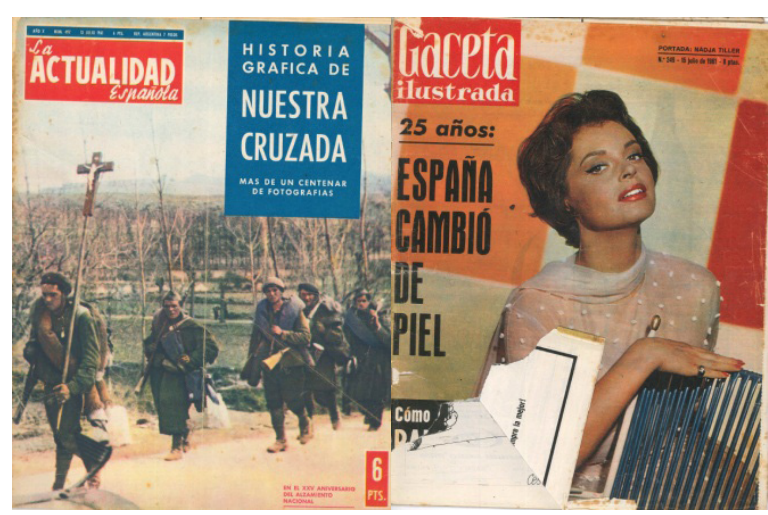

Figura 1

La portada de La Actualidad Española cuenta un relato en dos tiempos, al fondo, el pasado; en primer plano, el presente. El pasado se cuenta a través de una imagen fotográfica, prueba de imparcialidad, que representa la consecuencia de un acontecimiento anterior: el estallido de la guerra del 36. Esto es así, porque en la imagen pueden verse cinco soldados armados marchando por el campo con una cruz como estandarte, símbolo del bando al que pertenecen. El texto dedicado al presente es verbal: por una parte, está la cabecera de la revista, con el número de ejemplar, la fecha de su publicación y el precio. Por otra, el titular del reportaje principal. Abajo a la derecha, un breve texto en mayúsculas: "En el XXV aniversario del alzamiento nacional". Éstas (la fecha de publicación y la mención al 25 aniversario) son las únicas huellas de contemporaneidad. Puede decirse que el texto cumple aquí una función de anclaje (Barthes, 2000: 30), fundamental para interpretar el nivel connotativo del texto visual. Las palabras "historia", "nuestra cruzada" y "alzamiento nacional" indican la lectura correcta: Guerra Civil española, bando nacional. La palabra "cruzada" selecciona, sin lugar a dudas, el sentido de la cruz de la imagen. Es curioso que, a pesar de que ambos textos verbales (cabecera y titular) sirvan para anclar el significado de la imagen, uno de ellos (el del membrete que reza: La Actualidad Española) no parezca estar en sintonía con él: ¿cómo puede ser una foto que detiene el tiempo en un momento cualquiera de 1936 "la actualidad española" de 1961 ?

La portada de Gaceta Ilustrada cuenta tres relatos en un tiempo, 
el presente. El fondo de la portada es también una imagen fotográfica, pero una imagen contemporánea, la de la entonces famosa actriz austriaca Nadja Tiller. En primer plano tres textos verbales: la cabecera de la revista y los titulares de dos de los principales reportajes en el interior. Cierto que los titulares lucen verbos en pasado, pero parecen dispuestos a narrar procesos de cambio; su tiempo no está detenido.

De este modo, mientras que para La Actualidad Española la contienda es tan importante que decide dedicarle la totalidad de su portada y emplear ese día un diseño especial, un poético titular y una imagen simbólica, para Gaceta Ilustrada no merece ni siquiera una mención al margen; para esta revista lo importante no es la guerra sino el proceso de cambio en que desembocó. Así, al tiempo que Gaceta Ilustrada se proyecta hacia el futuro y envía mensajes de cambio, desarrollo y prosperidad, $L a$ Actualidad Española sigue anclada en el pasado, llenando sus páginas con más de cien imágenes congeladas de 25 años atrás.

\subsection{Los índices}

Lo siguiente es fijarnos en los índices, a saber, titulares, autores y números de página.

Índice de La Actualidad Española:

(- "Cartas de los lectores", pp. 3-6.

"En la muerte de don Eduardo Torroja Miret", p. 8.

"Notas de redacción", p. 8.

Editorial: "El 18 de julio, hoy", p. 10.

— "Historia gráfica de nuestra cruzada", por José Montero Alonso, pp. 13-56.

$\checkmark$ “Interpretación del 18 de julio", por Jesús Arellano, pp. 59-61.

Índice de Gaceta Ilustrada:

— "Carta al lector" (media página), p. 11.

$\checkmark$ Espejo de los días (sección): "Recuerdo y olvido", por José María Pemán, p.13.

$\square$ "La gran aventura: el salto del estrecho", pp. 14-19. 
— “España cambió de piel. La revolución desde la entraña", por Waldo de Mier, pp. 20-29.

$\checkmark$ La noticia y su clave (sección): "La Jauja de Kuwait", por Ramón Cunill, p. 30.

(— "Peter Ustinov, capitán de fragata", pp. 34-37.

U Un médico en G.i. (sección): "Defiende tu vida", por Orión, p. 40.

$\square$ Estadio de G.i. (sección): "El porvenir es nuestro", por Antonio Valencia, p. 43.

$\square$ Tercio de toros (sección): "Don Ernesto y los toreros", por Selipe, p. 45.

- "Manuel Halcón ama el campo y vive en la ciudad", por Federico Villagrán, pp. 46-51.

(- La vida sigue (sección), por Alfonso Sánchez, pp. 52-57:

- "La novia de Sacha Distel"

- "Katherina y Eduardo Kent, enemigos de los fotógrafos"

- "Lola (Flores), Antonio y Lolilla, en el Mediterráneo"

- "Tumulto contra los suspensos (en Francia)"

- "La medicina en el ruedo"

$\checkmark$ Héroes para todo (sección): "Su vida, para probar un salvavidas", pp. 58-59.

$\square$ “Cómo casé a Raniero", por Pierre Galante, pp. 60-66.

El primer vistazo al índice ya nos ofrece información importante. Destacan dos diferencias, una cuantitativa y otra cualitativa. La primera salta a la vista: La Actualidad Española publica un único reportaje que se extiende a lo largo de 44 páginas, el resto son cartas de los lectores, una necrológica, notas de redacción, el editorial y un artículo de opinión. Gaceta Ilustrada, por el contrario, edita cinco reportajes, además de una carta al lector y siete secciones fijas de opinión, crítica taurina y ecos de sociedad. La segunda, aunque relacionada con la primera, tiene que ver con el contenido de esos reportajes: La Actualidad Española dedica su reportaje principal, su editorial y su único artículo de opinión al 25 aniversario de la Guerra Civil, a saber, 37 de sus 39 páginas y media de tipo redaccional (el 94\%), sin contar la portada, que también. Contando la portada, serían 38 de 39 y media (el 96\%). Gaceta Ilustrada, sin embargo, no dedica a este aniversario más que un artículo de opinión y un reportaje 
de seis páginas, 7 de las 36 páginas disponibles (el 19\%).

Esto ya es bastante explícito. Mientras La Actualidad Española se ocupa de la política, Gaceta Ilustrada mantiene un tono ligero, casi de revista del corazón, atento a la actualidad nacional e internacional, los espectáculos, las curiosidades y los famosos de dentro y fuera de España. Sus páginas mezclan el recuerdo de la Guerra Civil, la revolución agraria, el rodaje de Fragata infernal (la última película del inglés Peter Ustinov) y la vida del escritor y político franquista Manuel Halcón, con la novia del cantante francés Sacha Distel, los duques de Kent, Lola Flores y la pareja formada por Raniero de Mónaco y Grace Kelly.

Pero hay más. El reportaje principal de La Actualidad Española lo firma un periodista de raza, José Montero Alonso, Premio Nacional de Literatura en 1928 y en 1944; el artículo de opinión, el filósofo Jesús Arellano. Vemos en Gaceta Ilustrada muchos más trabajos firmados, y las plumas, prestigiosas también, están todas comprometidas con el régimen franquista: el periodista, dramaturgo y poeta José María Pemán; el reaccionario Waldo de Mier; el sacerdote catalán Ramón Cunill; y Alfonso Sánchez. Firma también el periodista de Paris Match Pierre Galante.

Los titulares son también significativos. Centrémonos en los títulos de los artículos relacionados con el aniversario de la Guerra Civil para ver cómo diferentes palabras y asociaciones de palabras expresan un mismo concepto.

Los titulares de La Actualidad Española:

$\square$ "El 18 de julio, hoy"

— "Historia gráfica de nuestra cruzada"

$\square$ "Interpretación del 18 de julio"

Los titulares de Gaceta Ilustrada:

— Espejo de los días (sección): "Recuerdo y olvido"

$\square$ "La gran aventura: el salto del estrecho"

$\square$ "España cambió de piel. La revolución desde la entraña"

$\square$ Estadio de G.i. (sección): "El porvenir es nuestro"

Es difícil no fijarse en la enunciación, la manera en que la subjetividad emerge del discurso, según Benveniste (1977). En tres de estos titulares 
podemos hablar de desembrague enunciacional, que reconocemos gracias a un deíctico temporal (el "hoy" de "El 18 de julio, hoy") y el uso en dos ocasiones del plural de la primera persona (el "nuestra" de "Historia gráfica de nuestra cruzada"; y el "nuestro" de "El porvenir es nuestro"). Esto no es más que una estrategia discursiva que tiende a construir un efecto de identificación que no puede ser otra cosa que un simulacro, puesto que la situación en que el enunciado fue producido se perdió para siempre el mismo día en que se publicaron las revistas. Es, pues, una identificación tan fingida en su día, 18 de julio de 1961, como lo es hoy. Aun así, el uso de estas marcas es muy interesante porque, en el caso del periodismo, dictan las convenciones que el autor debería permanecer ausente con el ánimo de dar la impresión de ser objetivo. Otra cosa es que esta impresión se corresponda con una objetividad real, pero es especialmente revelador que no uno sino tres periodistas apuesten desde el mismísimo titular por la identificación, renunciando así a crear el tan perseguido efecto de objetividad (Tuchman, 1972).

No obstante, La Actualidad Española y de Gaceta Ilustrada construyeron efectos de identificación diferentes. Podemos decir que, mientras la primera promueve el acercamiento de la guerra a su tiempo y a sus lectores ("El 18 de julio, hoy", "nuestra cruzada"), la segunda promueve el alejamiento: lo que es suyo, "nuestro", no es la guerra, sino "el porvenir". El resto de títulos de Gaceta Ilustrada no hace sino confirmar esta impresión, gracias a la estrategia discursiva contraria, el desembrague enunciativo y sus marcas como el topónimo España, el verbo en pasado o el uso de la tercera persona. El pasado de "España cambió de piel" es, como el uso de deícticos temporales, espaciales y personales, contrario a las convenciones del discurso periodístico, en el que tiende a dominar el presente.

Hay también un mecanismo retórico, una metáfora, que comentar: "cruzada". La primera acepción de la palabra en el diccionario de la Real Academia Española dice: "Expedición militar contra los infieles, especialmente para recuperar los Santos Lugares, que publicaba el papa concediendo indulgencias a quienes en ella participaran". Viene de cruz, por la insignia de ella que llevaban los soldados en el pecho. Esta metáfora es importante porque advierte de la oposición semántica (es decir, de significado) fundamental que encontraremos en el nivel más profundo de las estructuras semio-narrativas de este texto: Civilización vs. Barbarie. 
Esta es la oposición alrededor de la que gira el reportaje completo, el cuento que nos cuenta. Es evidente, además, qué personajes concretos encarnarán estas contraposiciones de fondo: Franco y los nacionales, la Civilización; los republicanos, la Barbarie.

La conclusión es clara: la simple lectura de los titulares evidencia que ambos medios manifiestan explícitamente su toma de postura respecto al hecho noticiable. Ninguna de las revistas renuncia a interpretar y valorar el 25 aniversario de la Guerra Civil. Ambas defienden la Guerra y su recuerdo, pero una, La Actualidad Española, con más ardor que la otra.

\subsection{Los reportajes periodísticos}

Hasta este punto nos hemos fijado, someramente eso sí, en el fondo que sugerían los títulos de los reportajes, en su significado. Veamos ahora su forma, porque es evidente que la configuración visual de sus páginas refleja la relevancia, el valor, de cada uno de los reportajes y orienta nuestra interpretación. Sin ir más allá de número de páginas, superficie de titulares y textos, número de imágenes, ubicación de las noticias y combinación de colores, ya puede establecerse una jerarquía de reportajes en cada uno de los medios estudiados.

El reportaje principal de La Actualidad Española es la "Historia gráfica de nuestra cruzada". Se trata de un amplísimo reportaje, un especial que ocupa la portada y se extiende a lo largo de 44 páginas que son, además, las páginas centrales de la revista (pp. 13-56). Contiene 109 imágenes (103 fotografías, cuatro dibujos de mapas y dos fotogramas) entre las que destaca la única foto en color de la revista, exceptuando la publicidad: ocupa dos páginas completas y representa el Valle de los Caídos; el hoy controvertido espacio era celebrado ayer.

Lo más original de este reportaje es su portada, en virtud de la que la página 13 de La Actualidad Española de julio de 1961 se convierte en la primera página del Diario Regional de Valladolid del 19 de julio de 1936 cuyo título, escrito en enormes letras mayúsculas entre signos de exclamación rezaba: “iViva España!”. Bajo el titular, sobre fondo negro y en primer plano, el título del reportaje propiamente dicho: "Historia de nuestra cruzada". 


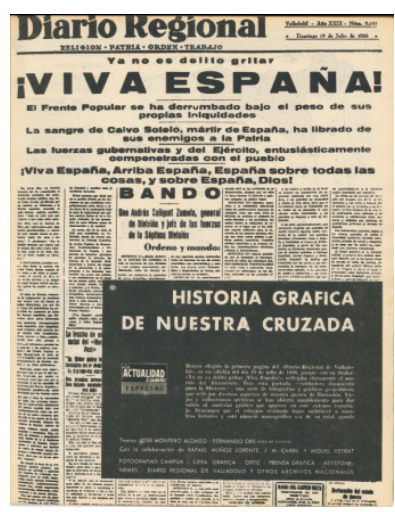

Figura 2

Es una solución ingeniosa puesto que la utilización de una imagen de archivo (la portada de un periódico antiguo) a la que se le superpone el título del reportaje consigue presentar de manera contemporánea las dos fases, primera y última, del largo relato que propone al lector. Así, el acontecimiento sobre el que se quiere llamar la atención está en primer plano, mientras que el acontecimiento anterior, el estallido de la Guerra, es representado al fondo. El paso de una fase de la narración a otra queda subrayado por la modificación del espacio representado: al fondo, el pasado, negro sobre blanco; en primer plano, el presente, blanco sobre negro. Todo esto se hace, además, sin perder un ápice de verosimilitud (el documento elegido no es otro que la primera página de un diario, prueba de vida donde las haya) y ganando coherencia, puesto que la simple vista de la portada del Diario Regional de Valladolid, con su fecha del 36, trae la Guerra al presente y redunda en el significado del editorial: "El 18 de julio, hoy".

En cuanto a las más de cien imágenes fotográficas publicadas por La Actualidad Española sobre la Guerra Civil, lo más evidente es su función testimonial. Las fotos están ahí para probar la veracidad del relato periodístico (su fidelidad se acepta por el hecho mismo de ser fotos, imágenes semiautomáticas, huellas efectivas de luz) pero, en realidad, no podrían ser más parciales. No es que estén trucadas, eso no. Las fotos son auténticas, lo que sucede es que retratan un único bando, el nacional, y con gran subjetividad. Lejos de plasmar la crudeza de una contienda civil, ofrecen, en conjunto, una visión del conflicto demasiado bonita para 
ser verdad: elegantes uniformes, alegres despedidas, grandes y ordenados actos político-religiosos, misas de campaña, desfiles, conmemoraciones, manifestaciones de "júbilo y adhesión"... Los soldados de La Actualidad Española aparecen casi siempre posando, desfilando o en formación, y sólo en tres ocasiones en acción.

Es cierto que esto pudiera quizá tener su origen en el estilo heroico de las imágenes de batallas realizadas en occidente desde el siglo XVI cuando, para mejorar la legibilidad de los cuadros, se sacrificaba el realismo rechazando deliberadamente la confusión y la dispersión de la guerra de verdad. Pero no. Muchos fotógrafos arriesgaron su vida por fotografiar el frente de batalla, pero La Actualidad Española no quiso publicar sus imágenes. Las que sí publicó ofrecen, sin embargo, un animado testimonio del modo en que los vencedores deseaban que se percibieran y recordaran los acontecimientos de la época. El reportaje especial "Historia de nuestra cruzada" es, en definitiva, un ejemplo espectacular de la Historia escrita por los vencedores.

Atendiendo a las características citadas (número de páginas, superficie de titulares y textos, número de imágenes, ubicación de las noticias y combinación de colores) los reportajes principales de Gaceta Ilustrada son:

— "España cambió de piel. La revolución desde la entraña": estas diez páginas, firmadas por Waldo de Mier, son de las primeras de la revista (pp. 20-29) y contienen ocho imágenes. El reportaje se anuncia en portada y ocupa diez páginas, las seis primeras sin publicidad, es decir, a toda página; las cuatro últimas a media página. El titular ocupa dos páginas.

૫ "Peter Ustinov, capitán de fragata": estas cuatro páginas, de autor desconocido, son las páginas centrales de la revista (pp. 34-37) y contienen siete imágenes a todo color. No comparten su espacio con la publicidad.

૫ “Cómo casé a Raniero": estas seis páginas, firmadas por Pierre Galante, son las últimas de la revista (pp. 60-66) y contienen cinco imágenes en blanco y negro. El reportaje se anuncia en portada y ocupa seis páginas, las tres primeras sin publicidad, a toda página; las tres últimas a media página. El titular ocupa dos páginas. 
Esto confirma lo escrito hasta el momento. Mientras La Actualidad Española permanece aferrada al pasado y dedica 40 páginas y un centenar de fotos a una guerra que acabó hacía 25 años, Gaceta Ilustrada narra el proceso de cambio sufrido por el país desde entonces insistiendo en conceptos como regadíos, siderurgia, kilovatios y turismo. Mientras, en el fondo, La Actualidad Española hablaba de civilización frente a barbarie, Gaceta Ilustrada habla de riqueza frente a pobreza.

\subsection{Los anuncios publicitarios}

Los anuncios publicitarios aúnan las dos revistas (entre sus 86 anuncios hay, de hecho, once repetidos, el 13\%, de modo que los anuncios estudiados son 75) y forman un corpus bastante rico, de sustrato popular, que refleja sin querer la cultura de la época. Sus insistencias temáticas indican tres cuestiones.

La primera, el tipo de producto que se anunciaba en las revistas populares:

$\square$ Productos de belleza (43\%): jabones, lápices de labios, perfumes, cremas solares, desodorantes, cremas depilatorias, champús anticaspa, after shaves...

$\checkmark$ Productos para el hogar (11\%): detergentes, insecticidas, frigoríficos, cocinas, colchones...

$\square$ Comidas (9\%): galletas, sopas, helados, leche condensada...

$\square$ Bebidas (8\%): café y bebidas alcohólicas como brandy, ron, whisky escocés o champán.

La segunda, los valores que prometían:

$\square$ Belleza (21\%).

○ Comodidad (11\%).

0 Limpieza (8\%).

Elegancia (5\%).

$\square$ Salud y juventud (4\%).

La tercera, que el público objetivo de los anuncios era 
fundamentalmente femenino; así, el $41 \%$ de ellos se dirige a las mujeres (jóvenes y elegantes, suelen especificar) y el 16\% a los hombres.

Las formulaciones visuales de los anuncios corroboran esto último, por lo que no es de extrañar que muchos de los anuncios (36\%) tengan como protagonista principal la imagen de una mujer, que siempre resulta ser joven y bella. De los seis hombres que aparecen solos en los anuncios, sólo uno es simplemente joven y bello; el resto aparece caracterizado como agricultor, pescador, camionero o mecánico. En nueve ocasiones, es la imagen del propio producto la que protagoniza el anuncio.

En general, los anuncios se muestran visualmente abigarrados. Casi todos presentan, aparte de las imágenes de sus protagonistas (la recurrente mujer joven y bella), una imagen del producto anunciado (76\%) y la típica necesidad de énfasis creciente del discurso publicitario, representada en lo visual por combinaciones de ocho, diez, once tipos de letra, el uso de la negrita, y el abuso de signos de exclamación y puntos suspensivos.

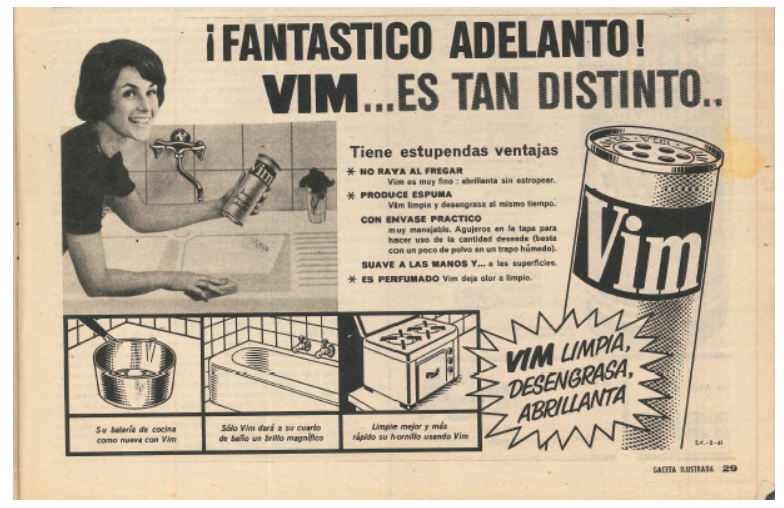

Figura 3

Este anuncio del detergente Vim es, quizá, el más representativo. Casi todos son así, ejemplos extemporáneos de lo que los historiadores de la publicidad denominan "publicidad científica", que nació en los años 20 en Estados Unidos y se extendió por todo occidente durante las siguientes décadas. Vemos, pues, que sus técnicas (la principal: enumerar las ventajas del producto y repetirlas una y otra vez) se seguían utilizando en la publicidad española de los 60, a pesar de que había pasado más de una década desde la revolución creativa de Madison Avenue.

Este de Vim sería clasificado por Floch (1997) como publicidad 
referencial. Quizá abuse un poco de los adjetivos, pero está claro que trata de dar la impresión de sinceridad y realismo. De ahí que la imagen de la mujer sea una fotografía en vez de un dibujo, que el producto (el envase del producto, mejor; típica metonimia publicitaria) sea el centro de atención, y que texto e imagen se relacionen de modo que los dibujos del caso, la bañera y la cocina muestren y demuestren lo escrito.

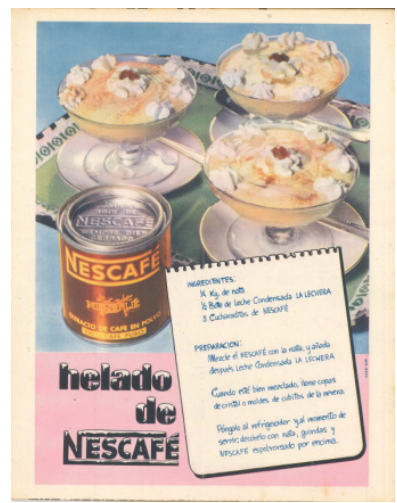

Figura 4

El hecho de que prácticamente todos los anuncios estudiados sean como éste, no hace sino subrayar la importancia de las excepciones. Porque también se han encontrado ejemplos de publicidad sustancial, muy parecida a la anterior, aunque más centrada en el producto. Es el caso de este anuncio de Nescafé, en el que el producto mismo se convierte en deseable; está ahí, nítido y frontal, casi como si pudiéramos tocarlo.

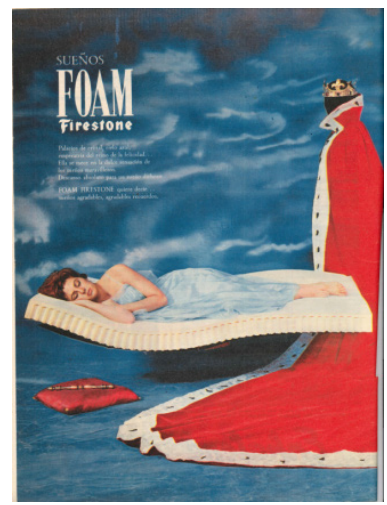

Figura 5 
He aquí otra excepción, ejemplo casi literal de publicidad mítica, en este caso. Dado que el producto anunciado es un colchón, parece pertinente revestirlo de sueños e intentar hacer fantasear al lector. De ahí que quien parece la reina de un cuento tradicional (¿Blancanieves?) vigile el sueño de... ¿la bella durmiente? Los símbolos míticos y fascinantes están claros (el manto real, la corona, el cetro, el vaporoso camisón azul) pero no combinan bien, por lo que el sentido del anuncio no queda del todo claro.

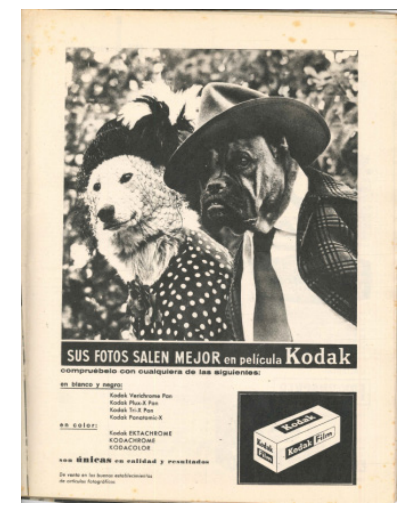

Figura 6

Por último, un ejemplo de publicidad oblicua, este de Kodak, basado en el retrato de una pareja. Todo en la imagen resulta convencional, el fondo difuminado, la pose, el vestido... todo excepto los modelos, que resultan ser una pareja de perros. Una personificación visual que, al tiempo que destaca la originalidad del anuncio, sirve de crítica a los lugares comunes. Este anuncio de Kodak está un poco más cerca de la avenida Madison, donde en los 60 se concentraba la mitad del gasto publicitario del país (Tungate, 2007: 37) y, por tanto, las mejores agencias publicitarias y los mejores creativos de los Estados Unidos, que es lo mismo que decir que concentraba las mejores agencias publicitarias y los mejores creativos del mundo. 


\section{CONCLUSIÓN}

Este rápido vistazo semiótico a estos dos ejemplares de revista de 1961 ha resultado bastante revelador; ambas publicaciones dicen mucho sobre los modos, modas y maneras de la época, sobre su homogeneización. A saber, La Actualidad Española y Gaceta Ilustrada comparten cultura, tiempo comunicativo (julio de 1961) y universo discursivo (periodístico), pero es tan cierto que son diferentes como lo es que son iguales.

Expliquémoslo mejor. Como se ha visto tras el análisis, $\mathrm{La}$ Actualidad Española es más conservadora que Gaceta Ilustrada. La primera dedica todo el número al 25 aniversario de la Guerra Civil, y sus dos únicas páginas no publicitarias en color son para una fotografía a dos páginas del Valle de los Caídos; la revista se publicó en 1961 pero parece anclada en el 36. La segunda, sin embargo, sólo dedica siete páginas a la guerra (hay tres reportajes más relevantes, con mucho más peso visual) y sus tres páginas en color son para el rodaje de una película... Este semanario habla de "olvido" y de "porvenir", sus palabras más puestas en el futuro que en el pasado; "España cambió de piel" y ahora es un país moderno y abierto al mundo (dos de sus reportajes principales hablan del rodaje de una película británica y de la boda de Rainiero de Mónaco).

Vemos, pues, que cada revista, en orden a sus valores, toma una posición pública diferente, la primera más conservadora y reaccionaria, la segunda más moderada. No obstante, el terreno sociocultural creado por ambas es el mismo, con un "nosotros" (los participantes) y un "ellos" (los excluidos) que coinciden. Al leer estas revistas, parece como si la sociedad española de los 60 no pudiera ser más que franquista. Las dos cabeceras interpretan de forma explícita y positiva la contienda que dividió al país un cuarto de siglo atrás, y ambas dan por hecho que sus lectores sólo pueden pertenecer al bando vencedor. Celebraron la Guerra Civil y la victoria de Franco, "nuestra cruzada", utilizando metáforas, sí, pero sin pizca de ironía...

Esto es muy revelador porque desvela lo que era posible en aquel tiempo, en aquel país, bajo aquel régimen. La publicidad lo corrobora. Los anuncios publicitarios insertados en ambos semanarios están lejos, muy lejos de la creatividad que aquellos años revolucionaba Nueva York. Una publicidad tan demodé como la España de 1961 y como esta comunicación. 


\section{REFERENCIAS BIBLIOGRÁFICAS}

BARTHES, R. (2000). Lo obvio y lo obtuso: imágenes, gestos, voces. Barcelona: Paidós.

BENVENISTE, E. (1977). Problemas de lingüistica general. México: Siglo XXI.

CASASÚS, J. M. (1985). Ideología y análisis de medios de comunicación. Barcelona: Mitre.

ECO, U. (1995). Tratado de semiótica general. Barcelona: Lumen $\left[1^{\mathrm{a}} \mathrm{ed}\right.$. 1975].

(1997). "Entre el autor y el texto". En Interpretación $y$ sobreinterpretación, U. Eco, ed., 80-103. Madrid: Cambridge University Press [1. ${ }^{a}$ ed. 1992].

FLOCH, J. M. (1997). Identités Visuelles. Paris: PUF.

FONTES, I. y MENÉNDEZ, M. Á. (2004). El parlamento de papel. Las revistas españolas en la transición democrática. Madrid: Grupo Anaya para la Asociación de la Prensa de Madrid.

KAYSER, J. (1966). El Periódico. Estudios de morfología, de metodología $y$ de prensa comparada. Quito: Ediciones CIESPAL.

LANDOWSKI, E. (2007). Presencias del otro. Ensayos de Sociosemiótica. Bilbao: Universidad del País Vasco UPV/EHU.

MORENO SARDÀ, A. (1998). La mirada informativa. Barcelona: Boch.

TUCHMAN, G. (1972). “Objectivity as Strategic Ritual: an Examination of Newsmen's Notions of Objectivity". American Journal of Sociology 77, 660-679.

TUNGATE, M. (2007). Ad Land. A Global History of Advertising. London: Kogan Page Limited.

Recibido el 15 de mayo de 2019.

Aceptado el 27 de junio de 2019. 